\title{
ПАТОЛОГІЯ ДИХАЛЬНИХ ШЛЯХІВ ПОРОСЯТ У РАЗІ ВПЛИВУ ІНФЕКЦІЙНИХ ЗБУДНИКІВ
}

\author{
Коваленко Лідія Михайлівна \\ кандидат ветеринарних наук, доцент \\ Сумський національний аграрний університет, м. Суми, Україна \\ ORCID: 0000-0002-4350-2284 \\ lidiia.kovalenko@snau.edu.ua
}

Коваленко Олександр Іванович

кандидат ветеринарних наук, доцент

Сумська регіональна лабораторія Державної служби України з питань безпечності харчових продуктів та захисту споживачів, м. Суми, Україна

ORCID: 0000-0001-6338-7917

Vetlabsumy@ukr.net

За результатами низки досліджень встановлено, що одними з проблем, які спричиняють зниження рентабельності тваринництва, стають респіраторні хвороби молодняку. 3 розвитком свинарства, оскільки це найбільш прибуткова галузь, ці хвороби поширені у багатьох країнах світу і посідають провідне місце в патології свиней (Grechukhin, Shafiev, 2012; Kovalishin, Kanypina, Byadovskaya, 2016). За останній період численними дослідженнями в нашій країні та за її межами встановлено, що хворобам молодняку сприяють технологічні стрес-фрактори, які знижують загальну неспецифічну резистентність та мають як неінфекційну, так і інфекційну природу. Велику питому вагу становлять респіраторні хвороби. Незважаючи на те, що епізоотологічна роль збудників інфекційної етіології досить вивчена, але у виникненні респіраторного синдрому у поросят залишається однією з гострих проблем. Різна видова належність в етіології захворювань шляхів дихання у молодняку забезпечує їх більш продовжене перебування в організмі. Упереджені господарські фрактори впливу утворюють бар'єр, який не дозволяє формуванню специфрічного захисту у разі інфекційних хвороб тварин, а імунопрофрілактика фракторним інфекціям, особливо без створення належних умов утримання і годівлі тварин. Науковиями доведено, що комплекс заходів боротьби з респіраторними хворобами поросят, окрім застосування засобів специфрічної профрілактики, проведення технологічних та ветеринарно-санітарних заходів, потребує застосування препаратів-імуностимуляторів та з антимікробною дією на супутні патогенні бактерії (Zuev, 2012; Bednarek, Pejsak, 2014). За даними дослідницьких робіт визначено, що специфрічна профрілактика великої кількості інфекційних хвороб не є ефективною, тому напрям у боротьбі з ними належить застосуванню комплексної терапії. Респіраторні захворювання мають асоиійовану форму, тому стає необхідністю застосування препаратів широкого спектра дії, одночасно впливаючи на декілька збудників. На сучасному рівні використовується антибіотикотерапія. Комплекс препаратів включає синергідний ефект, який дозволяє зменшити дозу того чи іншого препарату і тим самим удосконалити схему лікування інфрікованих тварин.

Ключові слова: збудник, імуностимулятор, антибіотик, бактерії, віруси, асоціація, інфрікованість.

DOI https://doi.org/10.32845/bsnau.vet.2021.3.4

Вступ. У центральній та північної частинах України важливе місце у сільському господарстві займають господарства 3 вирощування свиней. У галузі свинарства значну питому вагу займають інфекційні захворювання молодняку з переважним ураженням систем органів травлення та дихання. Одними 3 гострих проблем $є$ респіраторні хвороби вірусно-бактеріальної етіології. Вони дуже поширені в багатьох країнах з розвиненим свинарством, завдають відчутних економічних збитків та гальмують розвиток галузі (Baybikov, Gusev, Yaremenko, 2006). Інфекційні хвороби, такі як репродуктивно-респіраторний синдром свиней, цирковірусна інфекція, мікоплазмозна пневмонія, гемофілезний полісерозит, актинобацильозна плевропневмонія, пастерельоз, найчастіше протікають як змішана інфекція (Kareva, Arhipova, Bokun, Sazonova, 2011). Сучасна наукова діяльність спрямовується на розробку ефективних заходів боротьби з інфекційними хворобами (Grechukhin, Shafiev, 2012). Відкрита наукова тематика «Заходи боротьби та профрілактики захворювань тварин» ставить перед нами завдання проаналізувати епізоотологіющодовиникнення респіраторниххворобтваринугосподарствах північної частини України. Численні наукові дослідження свідчать, що у спеціалізованих свинарських господарствах спостерігається респіраторний симптомокомплекс, викликаний складною асоціацією збудників (Stark, 2016). Вiрус репродуктивно-респіраторного синдрому свиней, крім репродуктивної системи, вражає органи дихання, персистує в організмі свиней, розмножується в клітинах імунної системи, таких як лімфоцити і макрофраги, руйнує їх, призводить до імунодефіцитного стану (Kovalishin, Kanypina, Byadovskaya, 2016). У таких тварин створюються умови для залучення в інфекційний процес бактеріальних респіраторних патогенів, а саме мікоплазм, гемофільозних та актинобацильозних бактерій, пастерел та інших мікроорганізмів (Chiers, Donne, 2016). Незважаючи на впровадження сучасних технологій утримання та годівлі свиней, застосування широкого спектра біологічних та протимікробних препаратів, респіраторні хвороби, як і раніше, актуальні. Причинами 
такої ситуації, як констатують науковці, $€$ антигенне та патогенне різноманіття збудників, висока їх стійкість у зовнішньому середовищі, величезні адаптаційні можливості у протистоянні антимікробних препаратів, тривалий бактеріо- та вірусоносій у дорослих тварин, односторонній підхід до профрілактики (Fabisiak, Kita, Binek, 2010, Kohne, Huebert, 2012). За результатами наукових робіт встановлено, що пошук ефективних засобів та способів захисту тварин, розробка комплексної профілактики респіраторної патології є перспективним напрямом та потребує більш глибокого вивчення (Borghetti, Ferrari, Cavalli, 2009). Мета роботи - провести статистичний аналіз щодо епізоотологічної ситуації та етіологічної структури респіраторних хвороб свиней у господарствах двох областей, що межують; вивчити особливості клінічного прояву та патологоанатомічних змін у разі респіраторних хвороб свиней; дослідити чутливість виділених патогенів до антибактеріальних препаратів. На підставі досліджень вивчити профілактичну ефективність вакцини проти репродуктивно-респіраторного синдрому свиней; проаналізувати ефективність антибактеріальних препаратів нового покоління у разі респіраторних хвороб.

Матеріали і методи досліджень. Досліди проводили в умовах фермерських господарств СТОВ «Ранок», ТОВ «Беєво», ПСП «Камишанське» Сумської та Чернігівської областей. Статистичний матеріал стосовно епізоотології та етіології інфекційних хвороб був отриманий у протиепізоотичному відділі головного управління Держпродспоживслужби у областях, що межують. Окремі етапи досліджень проводили у відділах імунологічному, бактеріологічному та патоморфологічному Сумської регіональної лабораторії Державної служби України з питань безпечності харчових продуктів та захисту споживачів та ДНДІЛДВСЕ, використовували комплексний підхід, що включає сучасні методи досліджень. Проводили епізоотологічне обстеження господарств з виявлення джерел збудників інфекції, поширення, захворюваність, летальність. Аналізували протиепізоотичні, лікувально-просрілактичні заходи. Проводили клінічне дослідження тварин, патологоанатомічний розтин загиблих та вимушено забитих хворих свиней різного віку з оцінкою патологічного процесу. 3 метою вивчення етіологічної структури респіраторної патології проведено бактеріологічні дослідження патологічного матеріалу від свиноматок, поросят новонароджених та від тварин віком від 1-го до 4-х місяців, підсвинків на відгодівлі. Для досліджень відбирали уражені ділянки легень на межі здорової тканини, лімфатичні вузли, головним чином, середостінні, підщелепні, заглоткові, мезентеральні, кров із серця, селезінку, печінку з жовчним міхуром, нирки, трубчасту кістку; та ексудат з грудної та черевної порожнин. Патологічний матеріал досліджували не пізніше 2-х годин після його відбору. Висіви з патологічного матеріалу проводили на м'ясо-пептонний бульйон, м'ясо-пептонний агар, кров'яний агар, середовище Ендо, Плоскірьова. Також використовували інші спеціальні диференціально-діагностичні середовища. Посіви інкубували в термостаті за температури $37^{\circ} \mathrm{C}$ протягом 24 годин, після чого враховували характер зростання мікроорганізмів. У виділених чистих культурах вивчали морфологічні, тинкторіальні, культурально-біохімічні, серологічні властивості. Ідентифікацію виділених мікроорганізмів проводили за загальноприйнятими для мікробіології методами. Досліджено 76 проб патологічного матеріалу. Чутливість виділених культур до антибактеріальних препаратів визначали методом індикаторних паперових дисків згідно з «Інструкцією із застосування дисків для визначення чутливості до антибіотиків». В лабораторії вивчили чутливість до протимікробних препаратів штамів: Actinobacillus-66, Haemophilus-77, Pasteurella-33, Streptococcus-90, Bordetella-20, Salmonella-342, E. coli-794 цефалоспорини, фторхінолони, напівсинтетичні пеніциліни, сульфаніламіди, нітрофуранові, комплексні препарати сульфадокс, дизпаркол, лівозин. Вірулентність виділених культур мікроорганізмів вивчали у біопробі на білих мишах загальноприйнятими методами. Було вивчено профрілактичну ефективність вакцинації проти репродуктивно-респіраторного синдрому свиней. За принципом аналогів було сфрормовано дослідну та контрольну групи свиноматок по 20 голів у кожній. Свиноматки дослідної групи були імунізовані вакциною проти цього захворювання, контрольним тваринам вакцину не вводили. За тваринами вели клінічне спостереження протягом усього періоду поросності. Враховували також патологію поросності й опоросу, аборти, мертвонародженість, наявність нежиттєздатних поросят, вихід поросят на одну свиноматку. Надалі вели спостереження за тваринами від народження до відлучення від 28- до 30-денного віку. Враховували кількість хворих, полеглих поросят. Для вивчення ефективності імунізації молодняку проти респіраторного синдрому за принципом аналогів було сформовано дослідну та контрольну групи поросят після відокремленого періоду по 15 голів у кожній. Поросятам дослідної групи вводили вакцину дворазово з інтервалом 20 днів на 60-й та 80-й дні життя. Контрольним поросятам вакцину не вводили. За тваринами вели спостереження протягом 30 днів до переведення в іншу технологічну групу. Враховували кількість хворих і загиблих поросят. Ефективність вакцинації оцінювали за такими показниками, як захворюваність, летальність та збереження поросят. Профрілактичну ефективність антимікробних препаратів сульфадоксу, тіамуліну, енрофрлоксацину у разі респіраторних хвороб досліджували в умовах фермерських господарств на поросятах 1-2-місячного віку. За принципом аналогів було сформовано шість груп поросят по 15 голів у кожній. На основі результатів проведених досліджень та з урахуванням особливостей епізоотичного процесу етіологічна структура респіраторної патології була вдосконалена в умовах господарства «Комплексна система профрілактики респіраторних хвороб свиней». За принципом аналогів на ділянці дорощування було сформовано 5 груп поросят по 10 голів у кожній. За дослідними тваринами вели клінічний нагляд протягом 30 днів. Враховували кількість захворілих, загиблих поросят. Ефективність оцінювали за такими ж показниками. Загиблі тварини підлягали розтину, патологічний матеріал досліджували з використанням загальноприйнятих методів. Після 
закінчення досліджень провели розрахунок профілактичної та економічної ефективності. Значення в застосуванні комплексної профрілактики респіраторних хвороб свиней свого часу визначали (Kovalev, 2012). Весь цифровий матеріал був опрацьований біометрично. Отриманий цифровий матеріал піддали біометричній обробці з використанням програми Microsoft Excel з обчисленням середніх величин (М), їх середньостатистичної помилки ( $\mathrm{Im})$ та критерію достовірності (P), цифрові дані оцінили із застосуванням критерію достовірності при $\mathrm{P}<0,05$ (Kukushkin, 2010).

Результати досліджень. Під час вивчення епізоотичної ситуації у господарствах з вирощування свиней у Сумській та Чернігівській областях використали дані протиепізоотичного відділу головного управління Держпродспоживслужби. Останніми роки в областях спостерігається відносно стабільне епізоотичне благополуччя за класичними інфекціями, такими як класична чума свиней, бешиха, хвороба Ауески. Контроль епізоотичного процесу у разі класичної чуми здійснюється масовою імунізацією свинопоголів'я живими вірус-вакцинами з атгенуйованого штаму вірусу «К». Проте Чернігівська область $€$ зону зі складною та напруженою епізоотичною обстановкою з інфекційних хвороб молодняку свиней, у господарствах щорічно перехворіють на інфекційні хвороби від 35 до 60\% поросят. Як і раніше, актуальними залишаються колібактеріоз, сальмонельоз, дизентерія, вірусні гастроентерити, респіраторні хвороби. В аналізі структури інфекційної патології за 2018-2021 роки встановили, що нозологічний профріль інфекційних хвороб свиней було представлено переважно 11 нозоодиницями. Це шлунково-кишкові захворювання, які становили $34,1 \%$, у тому числі колібактеріоз - 12,7\%, сальмонельоз - 11,4\%, дизентерія - 6,5\%, трансмісивний гастроентерит - 2,9\%. Одне з місць посідає респіраторна патологія, така як мікоплазмоз, гемофрільозний полісерозит, актинобацильозна плевропневмонія - до 21,3\%, цирковірусна інфекція - в межах 13,6\%, респіраторний синдром - до 10,8\%, пастерельоз - 4,5\%. Нозологічний профріль інфекційної патології свиней на Сумщині має виражені регіональні особливості. Так, загалом у господарствах області діагноз дизентерія було встановлено у 4,3\% тварин, колібактеріоз та сальмонельоз - 10,2\%, респіраторні захворювання - 22,6\% від усієї інфекційної патології. Відзначено тенденцію збільшення респіраторних хвороб свиней. У структурі інфекційної патології вони становили у 2018 році $11,4 \%$, а 2019 році - 14,7\%, 32020 року мала тенденція до збільшення $-19,5 \%$ та у 2021 році показник становив $23,7 \%$.

Аналіз епізоотичної ситуації у фермерських господарствах показав, що респіраторна патологія реєструється протягом усього технологічного циклу. У поросят-сисунів вона виявлялася незначно і у структурі загальної захворюваності становила 0,3-1,2\%. У період дорощування респіраторні захворювання різко зросли до 31-46\% і у поголів'я на відгодівлі залишалися високими - 3 40,8\% до 57,6\%. Кількість загиблих поросят від респіраторних хвороб становила для поросят-сисунів 0,1-1,2\%, у молодняку на дорощуванні - 38,6-59,4\%, а на відгодівлі -
12,5-48,7\%. Під час бактеріологічних досліджень у лабораторних умовах з патологічного матеріалу нами були виділені збудники, такі як Mycoplasma hyopneumoniae від 9,3 до 48,7\%; Streptococcus suis - 19,7-36,2\%; Bordetella bronchiseptica - 23,5\%, Actinobacillus pleuropneumoniae - 41,8\%, Haemophilus parasuis - 19,6\%, Pasteurella multocida - 14,9\%, Salmonella cholerae suis 6,5\%, Escherichia coli - 45,7\%. Під час дослідження сироватки крові свиноматок та поросят методами ІФА та ПЛР була встановлена циркуляція вірусу респіраторного синдрому, цирковірусу 2 типу, що свідчить про інфікованість та вірусоносійство тварин. Зазначені збудники беруть активну участь у розвитку інфрекційного процесу, за якого створюються умови для активізації умовно-патогенної мікрофлори. В господарствах встановлено, що у виникненні та розвитку респіраторної патології поросят брали участь різні асоціації збудників. Змішані інфекції, спричинені вірусом респіраторного синдрому, ускладнені мікоплазмою, гемофільними бактеріями, пастерелою, протікали важче, ніж моноінфекції. Наявність бактеріота вірусоносіїв серед свиней створюють умови для стаціонарного неблагополуччя господарств 3 інфекційних захворювань. Клінічний прояв респіраторної патології залежав від збудників, форми та ускладненого перебігу інфекційного процесу. Характеризувався клінічною різноманітністю та пригніченням, прогресуючим виснаженням, відставанням у рості та розвитку, періодичною формою лихоманки. На початку захворювання визначався рідкісний кашель, потім переходив у тривалий, більш продовжений. Дихання поверхневе, прискорене, за значного ураження легень уривчасте, супроводжується задишкою, це підтверджено науковцями (Quintana, Segales, Rosell, 2010). Виділення з носових отворів ексудату різного характеру - від серозного до густого слизово-гнійного або пінистої кров'янистої рідини залежно від переважаючої нозологічної форми, ускладненої мікоплазмами, збудниками гемофрілозного полісерозиту, актинобацилярної плевропневмонії, стрептококової пневмонії. Такі ознаки $є$ спільними для всіх захворювань органів дихання. Результати наших досліджень показали, що патологоанатомічні зміни у разі респіраторної патології свиней характеризувались великою різноманітністю залежно від перебігу хвороби та збудників, залучених до інфекційного процесу. Загиблі тварини були різної вгодованості або виснажені та відзначався ціаноз шкіри вух, п'ятачка, міжщелепного простору, грудної та черевної стінок. Патологічний процес був представлений такими захворюваннями: пневмонією у 43,5\%$69,4 \%$ випадків, плевритом - 32,7\%-46,1\%, перикардитом - 29,4\%-39,1\%, плевропневмонією - 27,3\%-35,2\%, перитонітом - 28,6\%-39,7\%.

Розтин загиблих тварин дозволив встановити лімфраденіти регіонарних лімфатичних вузлів від 76,3\% до 85,3\% випадків, серозний набряк тканин -від 11,1\% до $17,4 \%$; запальні та дистрофічні зміни паренхіматозних органів, таких як селезінка, печінка, нирки, - від 72,3\% до 81,6\%. В лабораторних умовах провели діагностику різних штамів збудників на чутливість до різних препаратів. У разі діагностики штамів Pasteurella multocida, що досліджені протягом останніх трьох років, вони показали 
високу чутливість - від 83,2\% до 97,6\% - особливо до препаратів тіоцефуру, сульфадоксу, енрофлоксацину. Чутливість до оксицикліну знизилася до $34 \%$ з 76\%, а до таких препаратів, як гентаміцин, тилан, дизпаркол, фуразолідон, лише від 15\% до 23\%. Вивчення штамів Streptococcus suis показало високу чутливість до 87\% до сульфрадоксу, тіоцефуру, енрофрлоскацину, сульфодиметоксину. Такі препарати, як гентаміцин, тилан, фуразолідон, дизпаркол, показали антибактеріальну активність щодо Streptococcus suis від 27\% до 48\% випадків, а 93\% досліджених стрептококів були резистентними до амоксициліну та доксицикліну. Наші дослідження показали, що 98\% штамів Bordetella bronchiseptica виявили високу чутливість до гентаміцину, доксицикліну, амоксициліну, тіоцефуру, сульфадоксу, енрофрлоксацину, тилану, дизпарколу та на 83\% до сульфадиметоксину. Ми встановили 99\% резистентність штамів Bordetella до фуразолідону. Вивчення штамів Salmonella choleraesuis показало, що препарати енрофлоксацину, тіоцефуру, дизпарколу були активними з 85\% до 92\% випадків. Чутливість гентаміцину та тилану відповідно з 49\% до 51\% штамів. Ми спостерігали стрімке збільшення резистентності у сальмонел з 58\% до 100\% до таких препаратів, як амоксицилін, доксицилін, фуразолідон, сульфадокс, сульфадиметоксин.

Вивчаючи антибіотикограми штамів E. coli, встановили високу чутливість лише до двох препаратів - енрофрлоксацину та тіоцефуру, відповідно $87 \%$ та 91\%. Зазначили різке зниження чутливості ешерихій до гентаміцину до 32\%, дизпарколу з 61 до 17\%, амоксициліну до 13\%. Виділення резистентних штамів $E$.coli було дуже високим до фуразолідону 85\%, сульфрадоксу - 93\%, сульфрадиметоксину - 77\%, доксицикліну - 96\% та тилану - 94\%.

Обговорення. Науковцями вивчені антибіотикограми виділених збудників. Вони показали, що у фермерських господарствах з вирощування свиней в області, як і раніше, спостерігається селекція високорезистентних штамів мікроорганізмів щодо кількох груп протимікробних засобів. Профрілактика респіраторної патології свиней ґрунтується на комплексі заходів, що впливають на всі ланки інфекційного процесу. На підставі одержаних результатів досліджень була удосконалена у свинарських господарствах «Комплексна система заходів щодо профрілактики респіраторних хвороб свиней». За тваринами вели клінічний нагляд протягом 30 днів. Враховували кількість хворих, загиблих та тварин, що одужали. Ефективність такої системи оцінювали за такими ж показниками. Результати досліджень показали, що в контрольній групі у разі застосування тільки гентаміцину сульфату захворюваність поросят була високою до $68,6 \%$. Застосування вакцинації поросят проти репродуктивно-респіраторного синдрому сприяло зниженню захворюваності, летальності та значного збільшення збереженості тварин до 89,4\% порівняно з контролем.

Висновки. У Сумській області у структурі інфекційної патології вони становили у 2018 році 11,4\%, а 2019 році 14,7\% , 2020 року мала тенденція до збільшення - 19,5\% та у 2021 році показник становив 23,7\%. У поросятсисунів респіраторна патологія виявлена від 0,3\% до $1,2 \%$, у період дорощування вона різко зросла від $31 \%$ до 46\%, у поголів'я на відгодівлі залишалася високою з коливаннями 40,8\% до 57,6\%. Під час бактеріологічних досліджень виділені збудники, такі як Mycoplasma hyopneumoniae - від 9,3 до 48,7\%; Streptococcus suis - 19,7-36,2\%; Bordetella bronchiseptica - 23,5\%, Actinobacillus pleuropneumoniae - 41,8\%, Haemophilus parasuis - 19,6\%, Pasteurella multocida - 14,9\%, Salmonella cholerae suis -6,5\%, Escherichia coli - 45,7\%. Патологічний процес був представлений такими захворюваннями: пневмонією у 43,5\%-69,4\% випадків, плевритом -32,7\%-46,1\%, перикардитом - 29,4\%-39,1\%, плевропневмонією - 27,3\%-35,2\%, перитонітом $28,6 \%-39,7 \%$, лімфаденітами регіонарних лімфатичних вузлів - від 76,3\% до 85,3\%.

\section{Бібліографічні посилання:}

1. Bajbikov, N., Gusev, T.Z., Jaremenko, A.A. (2006). Reproduktivno-respiratornyj sindrom. Veterinarija s.-h. zhivotnyh [Reproductive and respiratory syndrome. Veterinary agricultural animals]. Ufa: Logos. № 12. 9-13 (in Russian).

2. Grechuhin, A.N., Shafiev, A.P. (2012). Diagnostika mikoplazmoznoj pnevmonii svinej. Veterinarnaja praktika [Diagnosis of porcine mycoplasmous pneumonia. Veterinary practice]. Kishinev: SKP. № 1. 10-15 (in Russian).

3. Grechuhin, A.N. (2017). Novoe sredstvo profilaktiki i lechenija bakterial'nogo respiratornogo simptomokompleksa. Svinoferma [A new means of prevention and treatment of the bacterial respiratory symptom complex. Pig farm]. Ufa: Logos. № 7. 53-56 (in Russian).

4. Zuev, O.E. (2012). Racional'naja antibiotikoterapija respiratornyh zabolevanij svinej i pticy. Veterinarnyj zhurnal. Sel'skohozjajstvennye zhivotnye. [Rational antibiotic therapy for respiratory diseases in pigs and poultry. Veterinary journal. Farm animals]. Voronezh: Research Institute. № 2. 18 (in Russian).

5. Kareva, Je.P., Arhipova, N.G., Bokun, E.A., Sazonova, E.A. (2011). Bakterial'nye respiratornye bolezni svinej. Veterinarnaja praktika [Pig bacterial respiratory diseases. Veterinary practice]. Kyiv: Vetinform. № 1 (52). 40-42 (in Ukrainian).

6. Kovalishin, V.F., Kanypina, A.B., Bjadovskaja, O.P. (2016). Diagnostika infekcionnyh boleznej svinej [Diagnostics of infectious diseases of pigs]. Kyiv: Vetinform. № 2. 15-16 (in Ukrainian).

7. Kovalev, M.M. (2012). Immunoprofilaktika i terapija boleznej molodnjaka. Aktual'nye problemy boleznej molodnjaka $v$ sovremennyh uslovijah [Immunoprophylaxis and therapy of diseases of young animals. Actual problems of diseases of young animals in modern conditions].Voronezh: Research Institute. № 5. 321-324 (in Russian).

8. Kukushkin, S.A. (2010). Metody diagnostiki reproduktivno-respiratornogo sindroma svinej. Veterinarnaja medicina. Mezhved. tematicheskij nauchnyj sbornik [Methods for the diagnosis of porcine reproductive and respiratory syndrome. Veterinary medicine. Interved. thematic scientific collection]. Kharkov: IEKVM. Issue 83. 133-137 (in Ukrainian).

9. Bednarek, D., Pejsak, Z. (2014). Principles of antibiotic therapy in swine respiratory disease. Med. Weter. Vol. 63. № 2. 140-144. 
10. Borghetti, P., Ferrari, L., Cavalli, L. (2009). Effect of weaning and vaccinations on immune and hormonal parameters in neonatal piglets. Veterinary Research Communications. Vol. 30. № 2. P. 227-230.

11. Chiers, K., Donne, E. (2016). Actinobacillus pleuropneumoniae infections in closed swine herds: infection patterns and serological profiles. Vet. Microbiology. Vol. 85. № 4. P. 343-352.

12. Fabisiak, M., Kita, J., Binek, M. (2010). Occurrence of gene encoding virulence factors in Streptococcus suis strains isolated from diseased and healthy carrier pigs. Med. Weter. Vol. 62. № 7. P. 785-787.

13. Kim, J., Chung, H.K., Chae, C. (2012). Association of porcine circovirus 2 with porcine respiratory disease complex. Vet. Journal. Vol. 166. № 3. P. 251-256.

14. Kohne, K., Huebert, P. (2012). Mixed respiratory infections associated with the porcine respiratory disease complex detected with multiplex-PCR. Proc. 19-th International Congress Pigs Vet Soc. Vol. 14. № 6. P. 313-315.

15. Quintana J., Segales J., Rosell C. (2010). Clinical and pathological observation on pigs with postweaning multisystemic wasting syndrome. Veter. Ree. Vol. 149. № 12. P. 357-361.

16. Stark, K.D. (2016). Epidemiological investigation of the influence of environmental risk factor on respiratory disease in swine. The literature Review. Vet. Journal. Vol. 159. P. 37-56.

17. Tracker, E.L. (2011). Diagnosis of Mycoplasma hyopneumoniae. Animal Health Res. Review. № 5. P. 317-332.

Kovalenko L. M., Candidate of Veterinary Medicine, Associate Professor, Sumy National Agrarian University, Sumy, Ukraine Kovalenko A. I., Candidate of Veterinary Medicine, Associate Professor, Sumy National Agrarian University, Sumy, Ukraine Pathology of the respiratory tract of pigs under influence of infectious patients

According to the results of a number of studies, it has been established that one of the problems that leads to a decrease in the profitability of livestock is the respiratory diseases of young animals. With the development of pig farming, as it is the most profitable industry, these diseases are common in many countries and occupy a leading place in the pathology of pigs (Grechukhin, Shafiev, 2012; Kovalishin, Kanypina, Byadovskaya, 2016). Recently, numerous studies in our country and abroad have shown that diseases of young animals are facilitated by technological stressors that reduce overall nonspecific resistance and have both non-infectious and infectious nature. Respiratory diseases account for a large share. Despite the fact that the epizootiological role of pathogens of infectious etiology has been studied, but in the occurrence of respiratory syndrome in piglets remains one of the acute problems. Different species in the etiology of respiratory diseases in young animals provides them with a longer stay in the body. Prejudiced economic factors create a barrier that prevents the formation of specific protection in infectious animal diseases, and immunoprophylaxis of factor infections, especially without creating appropriate conditions for keeping and feeding animals. Scientists have proved that the set of measures to combat respiratory diseases of piglets, in addition to the use of specific prevention, technological and veterinary measures, requires the use of immunostimulants and antimicrobial action on concomitant pathogenic bacteria (Zuev, 2012; Bednarek, Pejsak, 2014). According to research, it is determined that the specific prevention of a large number of infectious diseases is not effective, so the direction in the fight against them belongs to the use of complex therapy. Respiratory diseases have an associated form, so it becomes necessary to use drugs with a broad spectrum of action, while affecting several pathogens. At the present level, antibiotic therapy is used. The complex of drugs includes a synergistic effect, which allows to reduce the dose of a drug and thus improve the treatment of infected animals.

Key words: pathogen, immunostimulant, antibiotic, bacteria, viruses, association, infection. 